\title{
Universiteit
}

Leiden

The Netherlands

\section{Pathways to mitigate climate variability and climate change in Mali: the districts of Douentza and} Koutiala compared

Dijk, J.W.M. van; Bruijn, M.E. de; Beek, W.E.A. van; Dietz, A.J.; Ruben, R.; Verhagen, A.

\section{Citation}

Dijk, J. W. M. van, Bruijn, M. E. de, \& Beek, W. E. A. van. (2004). Pathways to mitigate climate variability and climate change in Mali: the districts of Douentza and Koutiala compared. In A. J. Dietz, R. Ruben, \& A. Verhagen (Eds.), The impact of climate change on drylands. With a focus on West Africa (pp. 173-206). Dordrecht: Kluwer. Retrieved from https://hdl.handle.net/1887/9664

Version: $\quad$ Not Applicable (or Unknown)

License: $\quad$ Leiden University Non-exclusive license

Downloaded from: https://hdl.handle.net/1887/9664

Note: To cite this publication please use the final published version (if applicable). 
In general it is recommended that monitoring studies be started (e $\mathrm{g}$ by using the same villages) to find easy early warning indicators of stress by combining efforts of the Ministry of Energy, Ministry of Food and Agniculture, Ministry of Lands and Forests, the Meteorological Service and strategic persons in the region

PATHWAYS TO MITIGATE CLIMATE

VARIABILITY AND CLIMATE CHANGE IN MALI: THE DISTRICTS OF DOUENTZA AND KOUTIALA COMPARED

Han van Dijk, Mirjam de Bruyn and Wouter van Beek Abstract Two Malian case studies are compared both representing dryland areas
with relatively low population densities and relattvely low levels of land degradation Douentza is in the seml-arid to arid zone, where crop cultivation is very risky and pastoralssm a more natural' way of making use of the environment However, recently crop cultivation has been expanding rapılly and has partally recovered from the droughts of the 1970s and 1980s Crop cultivation now provides a livelihood for impoverished former pastoralists (like FulBe and Tamachek), but also for groups who have always been cultwators (like the Dogon) Many people outginatung from thus area have extended therr geographical network and can be found in areas much further to the South Many retam therr relations with their areas of origin, though Koutala is an area in the sub humid zone and in a region which benefited from the Malan cotton boom economy of the 1980s and 1990s Not only did the local Minyanka prosper the expanding economy also provided a livelhood for many merts who had escaped the drought conditions of the northern area

\section{INTRODUCTION}

Climate change is not a phenomenon that can be instantly observed It manifests itself in small, gradual changes in temperature, evaporation and rainfall figures However, in the long term, climate change can have a tremendous effect, for example when the growing of a certain crop is no longer possible In semt-and environments, the variations in agroecological conditions in time and space are so great that small changes are hard to detect Climate change, therefore, tends to manifest itself as an mcrease in extreme events such as excessive rainfall or, at the 
opposite end of the scale, meteorological droughts. Policy makers need to be informed about the likely responses of the local population to such events in order to be able to implement measures to accommodate the consequences of any change in climate. This can only be done by a detailed analysis of local-level situations.

Over the past decades the Sahel has gone through one such phase of change which indeed seemed to be characterised by a noticeable increase in extreme events. However, it is not only the climate that is an unreliable partner in this area. Market prices and social institutions also respond to rainfall fluctuations, world markets, political unrest and so on An analysis of a whole set of contextual factors is therefore required. Risk and uncertainty are the most basic conditions for decision-making. This chapter considers the ways in which local farmers and herdsmen deal with climate variability and other uncertain contextual factors. The analysis is based on a comparison of two rural districts in Mali: Koutial in the semi-humid south of Mali at the $12^{\text {th }}$ parallel, and the district of Douentza south of the $15^{\text {th }}$ parallel, with its semi-arid climate.

In the first section, the outline of the research is discussed, followed by a short introduction to the research and the two research areas. The third scction offers an analysis of the pathways of local farmers and herdsmen in Koutiala and Douentza. In the final section, some conclusions are drawn with respect to the methodology used and to the pathways that have been developed over time by the various population groups in the study areas.

\section{THE TWO STUDY AREAS IN A COMPARATIVE PERSPECTIVE}

\subsection{The Research}

Research in the two areas consisted of a survey of the available literature supplemented with field research focused on specific groups of actors. In the Douentza District, previous research on the FulBe (or Fulani) herdsmen (De Bruijn \& Van Dijk 1995) was extended with additional research on a number of other population groups such as the Dogon group of cultivators (Maas 2001, Brandts 2001); the riimaybe, the former slaves of the FulBe (Griep 2001) and the various population groups of the district capital Douentza (Zondag 2000), as well as the trading Tamasheq from outside the area (Rutgers Van Der Loeff 2001). Specific topics such as agricultural expansion, the migration of FulBe

pastoralists (De Bruijn \& Van Dijk 1999) and the dynamics of the herbal and woody vegetation (De Boer 2001) were investigated. ${ }^{2}$

It was assumed that more information on the Koutiala area would be available in the form of research reports resulting from the long-term engagement of researchers with the Malian Cotton Company and agricultural research in the area. Most of this research was conducted either at regional and village level (Hijkoop \& Van der Poel 1989, Bosma et al. 1996) or focused on simulation models (Struijf-Bontkes 1999, Sissoko 1998) and did not deal with farming strategies in detail. In the end, two studies were made of two population groups, the Minyanka (Nikiéma 1999) and the immigrating FulBe (Van Steenbrugge 2001). The immigrating Dogon were covered while undertaking a study on agricultural expansion. Other basic data were obtained from non-ICCD research such as that conducted by Jonckers (1987, 1995), Degnbol (1999), Benjaminsen (2001) and Mosely (2001).

Both study areas are located in the Republic of Mali. Mali is a landlocked country inhabited by around 11 million people of whom $80 \%$ live in rural areas. Estimates of population growth vary between $2 \%$ and $3.2 \%$ a year according to the source (IOB 2000: 121). More than half of Mali's $1,230,190 \mathrm{~km}^{2}$ belongs to the Sahara and around $25 \%$ of the country can be used for agricultural purposes. Agriculture and animal husbandry in the Sahel and Sudan zone are subject to high risks, especially in the Sahel. The country's natural soil fertility is generally low and soils tend to be old and weathered. Levels of organic matter are depleted because of low levels of biomass production due to insufficient rainfall and high year-round temperatures causing an excessive rate of decomposition of organic matter.

Mali is one of the poorest countries in the world both in terms of economic production and human development. The agricultural sector accounts for most of its export earnings with cotton being the most important export item, accounting for almost half of all exports. It is followed by livestock, which is estimated to account for a further quarter of total export earnings. Average income in 2000 was $\$ 240$ (World Bank 2002: 233). However, income distribution is extremely uneven, with $69 \%$ of the population living below the poverty line in 1998. Poverty is concentrated in the rural areas where more than $80 \%$ of the population

${ }^{2}$ This research was carried out in collaboration with Wagenıngen University and Research Centre (Dept of Agronomy and Tropical Nature Conservation and Ecology of Vertebrates), Utrecht University (Dept of Cultural Anthropology), and the Amsterdam Research Centre for Global Issues and Development Studies (University of Amsterdam) 
was classified as poor in 1994 . In the cities, only $24 \%$ lived below the poverty line (IOB 2000: 124-5)

The study areas can be said to fall in the extremes of the povertywealth continuum. The district of Douentza is located in the Mopt region, the poorest in Mali in terms of economic and human development. Child mortality is high (200 per thousand in the first year of life and over 350 for all under-5s) and life expectancy is less than 40 years, probably even around $30-35$ years in the most rural areas (Hill 1991: 171-73, 178). These estimates are based on demographic research in Central Mali. For the whole of Mali, child mortality of the under-5s is estimated at 223 per 1000 and life expectancy at birth at 43 years in 1999 (World Bank 2002).

Koutiala is located in the Sikasso region and is the heart of the cotton-growing area. It is the wealthiest in terms of economic development and in its degree of urbanisation with two major cities, Koutiala and Sikasso (Staatz et al. 1989). The cash incomes of farming households are far above the national average (Degnbol 1999: 118) and most farming families own considerable assets (Assets owned per capita for tural households in the Siwaa area, southeast of Kout1ala varied between $\$ 96$ per capita in the poorest category to $\$ 358$ per capita for the wealthiest households; Mosely 2001: 138). However, if expenditures are considered, the region ranks as the second poorest after the Mopti region. Neither health provisioning nor educational levels are above average (Degnbol 1999: 120).

\section{$2.2 \quad$ Koutiala}

Koutiala District is located between $12^{\circ}$ and $13^{\circ} \mathrm{N}$ and between $5^{\circ}$ and $6^{\circ} \mathrm{W}$ (see map 13.1). The climate is Sudanic with rainfall concentrated in the months of June-October. Total annual precipitation amounts on average to $900 \mathrm{~mm}$ and varies between $15-20 \%$. Average temperatures are high, ranging from $22^{\circ} \mathrm{C}$ in the cold season in JanuaryFebruary to over $30^{\circ} \mathrm{C}$ during the hot season in May. Total rainfall declined in the 1970s and 1980s but recovered somewhat during the second half of the 1990s (see Figures 13.1a \& 13.1b).

The population density in the district is not (yet) very high. As of 1992 , more than 300,000 people were living in an area of $8.740 \mathrm{~km}^{2}$, resulting in densities of around 40 inhabitants per $\mathrm{km}^{2}$. Population growth is far above the national average of $2 \%$ due to the influx of poor migrants from the north. The district is mainly inhabited by Minyanka, with minorities of other ethnic groups such as the FulBe and Dogon. Some of the FulBe and all the Dogon are relative newcomers to the area and migrated there in the wake of the droughts of the 1970s and 1980s.

However, almost all the cultivable land has been put into production. Around the district capital of Koutiala, agricultural occupation has almost reached its maximum, whereas in the more remote areas more land is available and fallow cycles are still followed, though allowing land to lie fallow for long periods is no longer feasible (Hijkoop \& Van Der Poel 1989: 17). In densely populated areas, most of the land is under permanent cultivation (Hijkoop \& Van Der Poel 1989).

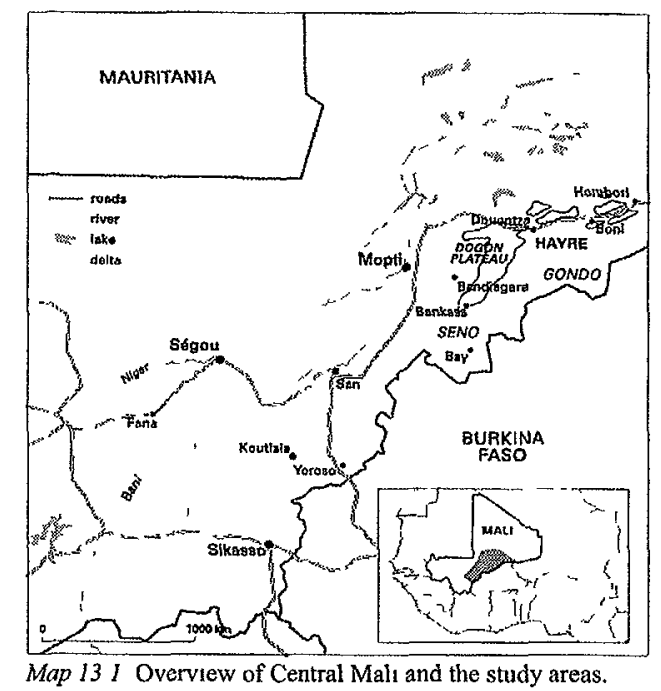

Altitude varies between $280-400$ metres above sea level and relief levels are gentle. Geologically, most of the district belongs to the Koutiala Plateau, consisting of low hills with gently undulating slopes. On the hills, the soils are characterised by hardpans, with shallow soils and large amounts of gravel in the subsoil. Lower down, the soils gradually change from loamy-sandy soils that are poorly drained and highly susceptible to erosion, via sandy-loamy soils to heavy more fertile clayey soils in the valleys. The natural vegetation consists of forest to tree savannah or shrub savannah.

On higher land, the main constraint on use is erosion, and in the valley bottom poor drainage imposes its own limitations. Usage is adapted to the soil qualities with the degraded soils mainly used as pasture area. Vegetation consists of annuals, trees and shrubs. Different soils are used for the cultivation of cereals: millet is grown in the driest and most shallow soils, and maize and sorghum in wetter soils and soils which are poorly drained. Cotton is cultivated near the valley bottoms where gardens, tree yards and dry-season pastures can also be found. 
The district's rural economy is founded on two pillars: the cultivation of cereals as a subsistence crop and the growing of cotton for cash. Millet, maize and sorghum account for more than two-thirds of the area cultivated and cotton makes up around $20 \%$. These figures may vary from one area to another with a share of up to $50 \%$ for cotton in some individual households. The rest is used for gardens, pulses and peanuts. Most farming units combine the cultivation of cereals and cotton. There are generally two types of farming systems, one predominantly oriented towards cereal cultivation in combination with cotton for cash, with livestock production for the provision of traction animals, manure and capital outlays for meagre years. The other system concentrates on transhumant livestock production with supplementary cereal production. In terms of numbers, the first system is by far the most dominant and is operated by sedentary farmers, the Minyanka, who are the main ethnic group in the area, and some Bamana. The livestock-based farming system is in the hands of the FulBe, who have moved in from other areas over time

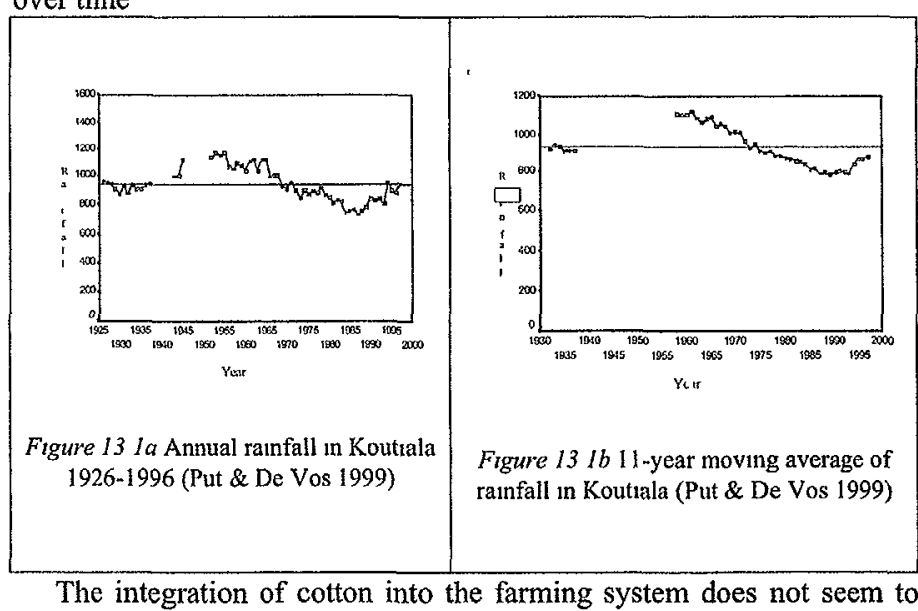
have affected food security for the large farming units. Most are selfsufficient with respect to basic food and are even capable of selling surplus production (Raymond et al. 1991). This is partly due to the introduction of new technology - mainly agricultural equipment and oxen traction. By now, most farming units possess agricultura equipment and the majority have at least one pair of oxen at their disposal. This has enabled farming units to expand their cultivated area and to combine cereal and cotton cultivation within the same unit. Livestock have become critical within the farming system. Given the high pressure on land and the almost permanent cultivation, the risks of soil erosion and the depletion of the soil's fertility are high. In this situation, organic manure is indispensable for the mantenance of soil CLIMATE

fertility, the stability of soil aggregates and to improve the efficiency of chemical fertilisers.

Consequently, the importance of livestock has increased tremendously since the introduction of cotton and the increase in population density. The cotton-growing area, Mali-sud, has surpassed the region of Mopti as the area with the largest number of cattle. The main livestock species is cattle, followed by small ruminants. Donkeys and horses are also raised for transport purposes. It is estimated that the number of livestock in Koutiala District far surpasses its carrying capacity as determined by agro-ecologists (Bosma et al. 1996, Hijkoop $\&$ Van Der Poel 1989). However, there is no evidence that this has led to degradation of the vegetation cover in terms of productivity. On the contrary, according to Mosely (2001: 109-10), biomass has increased in most of the south of Mali and remained constant in other parts over the 1982-84 and 1996-98 periods due to some improvement in rainfall figures during this time.

Institutional context

Linkages with other areas were limited in the past. There was little political centralisation in Minyanka society, in contrast to neighbouring areas such as the Inland Delta of the Niger and the Senoufou Kingdoms to the south. No major trade routes ran through the area.

During the colonial period, major changes swept through the area. After failed attempts in the pre-war era, a parastatal agency, the Compagnie Française de Développement des Fibres Textiles (CFDT) was established in 1949 to promote the production of cotton. Its success was based on stable and acceptable producer prices and a monopoly on the purchase, grinding and export of cotton, a system that has been labelled 'coercion of the markets' (Roberts 1995). After independence, the CFDT gradually took on other tasks, such as rural infrastructure, the extension for cereal cultivation, credit provision, farmers' organisations and literacy courses. In 1974, the Malian government was given $60 \%$ of the shares (Degnbol 1999: 115; The mother company of CFDT/CMDT, the French CFDT, is controlled by the French government that originally held $64 \%$ of the shares. Private interests owned the rest).

During this period the area under cotton cultivation increased dramatically. Since 1960, the area has increased six-fold, and in the decade between 1984 and 1994, the area under cotton almost doubled (Degnbol 1999: 115). Cotton production increased from 3,900 tons in 1958 to 68,000 tons in 1972 and 561,000 tons in 1998 (Benjaminsen 2001: 262). The devaluation of the CFA franc in 1994 helped boost cotton production from 310,000 tons in 1992 to 561,000 tons in 1998 . Productivity, that was around $200-250 \mathrm{~kg} \cdot \mathrm{ha}^{-1}$ in the $1950 \mathrm{~s}$, reached its highest point in 1990 with $1,376 \mathrm{~kg} \cdot \mathrm{ha}^{-1}$. Since then, levels of production have declined. In the main area around Koutiala, productivity decreased 
by $6.8 \%$ per annum during the $1993 / 94$ to $1997 / 98$ period. Total production was halved in 2000 following a farmers' strike when the CMDT lowered farm-gate prices to accommodate the collapse in world market prices (Tefft 2001: 218).

The CMDT success story until 1999 was based on an intensive model of vertical integration of the production chain. The CMDT controlled all the components of the production chain from the sale of inputs to the provision of credit and farming equipment, the processing and marketing of cotton and the execution of subsidiary programmes designed to combat soil erosion and deforestation. Since the 1980s the sale of inputs, credit provisioning and the purchasing of cotton have gradually been organised at village level by means of village associations (associatons villageoises).

The reverse side of this success story is the small margin between profit and loss. Any prolonged drop in world market prices pushes the CMDT into the red and farmers' prices go down. The slump in world market prices of the last few years has forced the CMDT to lower farm gate prices substantially. A further weakness in the CMDT model is the amount of control it exerts over the rural economy. Corruption and abuse of power by local CMDT agents and members of the boards of village associations, right up to the highest levels of management, have led to a growing discontent among farmers. This, in turn, has led to the emergence of a countervalling power in the form of a farmers' union, the SYCOV (Syndicat Cotonmer et Vivrter) (Bingen 1994), though critics argue that they are more outwardly oriented than acting as power brokers for their members (" $L$ 'une des faiblesses des syndicats paysans est leur faible capacité de communication. Ils n'ont pratiquement pas de référence (siège, numéro de téléphone, etc.). Ils sont plus connus a l'extérieur du Mali qu'à l'intérieur Il y a une confusion entre les fonctions de la coordination des AV et celle des syndicats. Par ailleurs, on a assisté à une bureaucratisation précoce des responsables de ces syndicats. Ils passent plus de temps dans les forums, ateliers et colloques que sur le terrain à renforcer leur syndicat. Ce falsant, ils n'arrivent pas à mobiliser les ressources internes. Ces syndicats sont obligés de recourir à des financements extérieurs pour survivre, ce qui menace leur indépendance. SYCOV est intégré à un réseau international et c'est la raison pour laquelle ses responsables sont assez souvent en voyage d̀ l'extérieur du Mall », De Brujn et al. 2001: 51-52). This contributed to the outbreak of strikes amongst farmers and rioting in Koutiala, where an important element of the CMDT infrastructure is vested. Others have argued that CMDT policies have contributed to a growing differentiation in wealth and vulnerability among CMDT clientele although the evidence is contradictory (see Moseley 2001, Degnbol 1999, Nikiéma 1999, Jonckers 1987, 1995).

\section{3}

\section{Douentza}

Just as Koutiala District is at first glance the wealthiest district in Mali, the Douentza study area is one of the poorest areas. It is part of the Mopti region and is the poorest in Mali economically and in terms of human development. The study area (see map), which belongs to the districts of Douentza, Koro, and Bandiagara, is located between the $14^{\circ}$ and $15^{\circ} \mathrm{N}$ and $2^{\circ}$ and $4^{\circ} \mathrm{W}$. The climate is Sahelian and rainfall amounts to $500 \mathrm{~mm}$ per annum in the south of the study area and $350 \mathrm{~mm}$ per annum in the north. It is close to the thermal equator, with an average annual temperature in Hombori just north of the area of $29.8^{\circ} \mathrm{C}$. Total annual rainfall shows a decreasing trend from the $1950 \mathrm{~s}$ and $1960 \mathrm{~s}$ onwards, recovering somewhat in the 1990s (see Figures 13.1a \& 13.1b).

Altitude varies between 250 and 800 metres above sea level and the area consists of three agro-ecological zones. The first is the Bandiagara Plateau, consisting mainly of rock that rises east of the Inland Delta of the Niger up to 700-800 metres high. The plateau ends in an escarpment at an elevation of 200-300 metres above the sandy plains of the Seeno and the Gondo. This escarpment with its watercourses at the bottom is the second sub-region. The third sub-region consists of the plains east of the escarpment. Near the escarpment, there are eolic dunes from the quaternary giving way to the east and the north to outcrops of the mountain formation. Here, clayey soils can be found. The relief levels are spectacular, with the Bandiagara Escarpment rising almost 300 metres above the Seeno and Gondo plains and the Inselberge that connect the plateau with Mount Hombori, the highest mountain in Mali.

The population density here is much lower than in Koutiala District. However the population distribution is extremely uneven. In Douentza District it is around 10 inhabitants per $\mathrm{km}$ whereas in the south of Koro District and along the escarpment in Bandiagara District population densities can be found that are higher than in Koutiala District. Annual population growth is around $1 \%$, indicating that emigration is higher than immigration. In some sub-districts along the Bandiagara Escarpment the population is actually decreasing. Dogon farmers mainly inhabit the study area, with a large minority of $\mathrm{FulBe}$, who are concentrated in the northern half of the area and on the sandy plains.

Cultivable land amounts to around $50 \%$ of the total area, as the rest of the land is susceptible to intra-seasonal drought because of its low waterretention capacity. Agricultural occupation further depends on the density of the population. In the south of the Seeno and Gondo plains and near the escarpment, $90-100 \%$ of the land is under permanent cultivation. To the notth where population densities are lower, the level of agricultural occupation is lower, although it is on the increase. Large tracts of land are still available as pastureland for livestock rearing. On 
the plateau, only $10 \%$ of the land is cultivable, the rest being rock or sol which is too shallow to support a crop. All the land that can be used is being cultivated on a permanent basis.

The diversity in soils is huge, ranging from deep sandy soils in the dune areas to clayey or loamy soils of differing depths on the plateau and the outcrops of the mountans. Their agricultural properties vary accordingly, as do the chemical properties of the clayey soils. Some are more fertile than the sandy soils, but where there is a lot of gravel or laterite in the subsoil, water for plant growth is low and crops are susceptrble to drought. Further crop damage may occur when these soils are poorly drained and the water stagnates after heavy rainfall. The sandy soils are much better drained but in general low in nutrients and, when the loam content is low, extremely susceptible to intra-seasonal drought. However, many farming units prefer the soils in the depressions as they contain some loam, are easier to work, fewer weeds grow and, when sufficiently fertilised, they can produce acceptable harvests. In most areas, millet is the main crop and is grown in monoculture in the north. Towards the south of the study area, millet may be found mixed with beans, whlle sorghum is sometumes grown on the heavier soils in depressions and valley bottoms. Market gardening takes place along watercourses and reservoirs created by dams on the plateau.

The economy of the region is based on the cultivation of cereals for subsistence and the rearing of livestock for meat and/or milk. For some on the plateau, market gardening is their main source of income. Remittances from migrants are an indispensable part of people's income because in most years parts of the study area do not produce sufficient grain and/or livestock to sustain the population. Even in urban centres, such as the district capitals, $(8,000-20,000$ inhabitants) most people have fields to produce millet. The urbanisation rate is low and does not exceed $10 \%$.

Over the past decades, technological development has led to an accelerated growth in the amount of land under cultivation. Agricultural equipment in the form of ploughs drawn by any kind of draught animal oxen, donkeys, camels or a combination of the three - is common throughout the whole study area. Though it seems that over a long period of time the productivity of the land declines under the impact of drought, total production has not declined because of the rapid increase in the acreage under cultivation.

Nevertheless, the northern part of the study area and the districts to the north are structurally deficient areas with respect to primary cereal production. To compensate for this deficit, livestock is the main cash earner in the area. In the southern part of the study area deficits occur only in drought years. In other years, it is a surplus area, provisioning the north of the study area and the areas further north towards Timbuktu (see Rutgers Van der Loeff 2001). Given the high degree of cultivation and the low level of rainfall, there is a lack of opportunities to compensate 
It is clear from the previous section that climate variability is much less of a problem in Koutiala than in Douentza. Consequently, the pathways of the local farmers and herdsmen are influenced much more by other factors such as markets and institutions than by rainfall levels and their distribution over time and space. Given its size, financial power and the degree of control the CMDT has over farmers, prices and institutions, it is the single most important actor shaping pathways. This does not mean that climate and the vulnerability of farmers is not a potential problem. Especially in the north of the area, rainfall figures are approaching the limits at which cotton cultivation is still possible (see chapter 10 , and 16 as well). Secondly, cotton cultivation may increase the vulnerability of households and individuals. Thirdly, the area has attracted a large number of migrants over the past few decades. How they integrated their strategies into the CMDT format and how they fare economically is largely unknown. Fourthly, there has been some debate about the nature and extent of poverty in the area. According to the statistics of the CMDT itself, the poorest categories of farmers, i.e. those without oxen-drawn agricultural implements, are slowly disappearing The question is whether these statistics cover all the farming units in the area and whether these poorest units are disappearing because they become wealthier or because they become even poorer. Their members may eventually move away or their unit may have become unviable and may have been taken over by other units, or may have died out. Finally, discussions about farmers' strategies in the area have been dominated by neo-Malthusian views pointing at the failure of farmers and intervening agencies such as the CMDT to achieve integrated soil management in a situation of population growth, declining rainfall and degrading natural resources. This failure is attributed to farmers' attitudes to labour and a short-term horizon due to their poverty (Koning et al. 1997). According to this line of thinking, the current wealth of the area is based on soil mining rather than sophisticated technological innovations (Van der Pol 1991). However, the empirical basis for such conclusions seems weak since they are based on weak databases. Moreover, the problem is caused by the enormous amount of land under cotton production that in turn has led to the shortening of fallow periods. The returns on labour from cotton cultivation are lower than for cereal cultivation (Raymond et al. 1991 : 193) and therefore do not justify further investments in soil conservation and soil fertility at farm level given opportunity costs in other sectors of the economy and the transaction costs for obtaining credit.

Increasing vulnerability Climate and markets

Questions about the vulnerability of farmers and the ecological environment have become more urgent. Farmers' protests against CMDT policies (and corruption) have increased following dramatic drops in world market prices and the CMDT's adaptation of farm-gate prices

\section{$C L_{y}$}

This led to a strike by farmers in 2000 , a $50 \%$ drop in cotton production and dealt a massive blow to the financial position of the CMDT potentially influencing Mali's national budget and its political stability. Efforts are now being made to restructure the cotton production sector.

The whole question of adaptation to climate variability and possible responses to climate change can only be answered with reference to the development of the cotton production and processing sector and the assessment of the vulnerability of various categories of farmers. Contrary to official statistics, some observers have pointed out that extensive poverty still exists in Koutiala District despite the developments in cotton production (Degnbol 1999). Jonckers $(1987,1995)$ noticed that, following the introduction of cotton production, fundamental transformations in Minyanka society in the role of women in social and economic life, religion, land tenure and informal social-security relations.

One of the main results has been rising economic inequality between farming units and especially between villages that are part of the CMDT extension system and those that have not been selected for the promotion of cotton production. The latter are not included in the official statistics. Consequently the main basis of social organisation, the lineage-based extended family is breaking up into small family units. In the absence of a village or regional-level organisation, this gap is being filled with institutions put in place by the CMDT such as the associations villagoises, which are known to be corrupt. Internal cleavages and political divisions within the villages associated with the administrative decentralisation currently underway may increasingly hamper their functioning (Nijenhuis 2002).

Minyanka farmers

There seems to be a difference between large and small farming units with respect to food security. According to Nikiéma (1999: 119), smalle units are more vulnerable to crop failure and less food secure than large units. Large farming units profit more from traditional forms of social security as well as from modern institutions like government services, the associations villageoises and farmers' unions. In addition, these larger units dispose of more livestock and are able to accumulate more capital savings by means of cash crops (cotton and also maize) and secondary activities. Smaller units also undertake these activities but they seem to be aimed at closing the cereal gap rather than accumulating savings and the formation of capital.

The principal difference between these poor and rich units is the level of farming equipment. Apart from rainfall, numerous other constraint affect food security such as access to land and labour, and marketing conditions. Rainfall variability is one of these important constraints 
because the units' structural positions do not allow them to develop more sophisticated strategies to counter this problem. For rich households, access to land is their major concern after rainfall variability, since in the main area of the cotton basin there is no more land available to put into production. The productivity of the land has also reached its limits. Cotton and cereal production is declining because soils are exhausted and less fertile land is being used for production. Nikiéma (1999) concluded that there is a progressive impoverishment of the poorer categories and only a few farming units that are managing to improve living conditions.

To deal with these problems, rich and resource-poor farmers follow different pathways and strategies differ widely even between farming units of the same category. Agricultural intensification remains limited to the category of wealthy farmers because of the capital outlays required. For resource-poor farmers the options are more limited within the domain of agriculture. Extensification, i.e. bringing more less-productive land into cultivation, is their main pathway. Besides agriculture, the main strategies are labour migration, the diversification of income sources and attempts to create larger farming units.

Case studies

Based on the material available it is not yet possible to differentiate between distinct pathways for various categories of decision-making in units in the Koutiala area. The current wealth situation of a household cannot be taken as a result of a specific investment strategy or an indication that units have been either poor or rich in the past. However, a number of trends can be observed in the manner in which households deal with variability, adversity and the minmmsation of risks.

An in-depth analysis of individual households shows that chance plays an important role in a group's fortunes despite the fact that many households have managed to build up considerable stocks of food and other assets to cope with hard times. This is due to the fact that not only rainfall is variable but also cotton prices and the labour markets in urban areas and abroad. For example, the death of a family's principal labourer may lead to a dwindling of assets. Drought, pests, disease affecting family members and other contingencies can have an enormous impact on a family's wealth and stock of assets. The influence of such events may last for years or even decades.

Another observation that can be made from the available research results so far is that despite the fact that cash income from cotton cultivation is considerable, most households do not manage to acquire more wealth in the form of livestock, or to consolidate their stock of assets. Instead, stocks of cereals have diminished over time in most of the households studied (Nikiéma 1999 also mentions in his case studies that the ownership of considerable herds of cattle also existed in the past and that young men even worked as cattle herdsmen in other places. The role of cattle in the management of soil fertility is, however, becoming more important, meaning that cattle and livestock in general have become the favourite form of investment). Jonckers (1995: 233) found the emergence of a category of wealthy farmers, but also observed 'une lente détérioration des qualités de vie et particulièrement de l'alimentation de certaines familles. Les greniers de réserves céréalières, indispensables pour pallier les sécheresses, et signes traditionnelles de richesse, se font rares, alors même que la production céréalière n'a pas globalement régressés dans la région'. This phenomenon is not limited to the decision-making of poor units only and there has been a general increase in vulnerability of food deficits, especially for rich households. Their risks equalled those of poor households in 1999 (Mosely 2001: 126), mainly due to the rate of indebtedness of these families.

The ways in which Minyanka decision-making units try to cover adversity are extremely varied. In agriculture, some of the pathways pursued are technological innovations, extensification, intensification, and new crop varieties. Cash income is also playing an increasingly important role. It is being generated by means of agricultural diversification (market gardening, fruit trees), wage labour (livestock herding, labour migration), trade and credit. For men and women, having different sources of cash income is the most important. Women engage in different income-earning activities and have other sources of credit to men (Nikiéma 1999).

Every household has its own specific mix of activities based on preferences, possibilities in terms of labour constraints and available capital and knowledge. Nikiéma (1999: 59-67) has shown, for example, how different the pathways have been for two brothers born in the 1940s and raised in the same compound and who farmed together on the same farm until 1984. Until then, the brothers undertook labour migration in turn. When they went their separate ways the elder brother took most of the family assets and had ten members in his compound. The younger had a family of five. Assets in the form of livestock and cereal reserves had been depleted. The cereal reserves decreased from five years to one and the family herd had been halved in the course of the 1970s because of drought and bad harvests and the large number of young children.

Cotton cultivation meant that the family of the older brother was able to rebuild the family herd somewhat during the second half of the $1980 \mathrm{~s}$. By speculating with the cereal reserves on the cereal market in drought years, they were also able to enlarge their assets and the family was able to invest in education for some of the children. The eldest son, having finished his studies as a veterinary technician, is working in the village as a private vet. This increases the family's social esteem. His wife prepares millet beer and one of his cousins, who lives in the compound, is the only carpenter in the village. 
The family is among the wealthiest in the village. Its cereal harvest amounts to $200 \%$ of consumption needs, not counting the revenues from cotton and all the cash income derived from non-agricultural activities. The main problems for this family are related to their cultivation activities. Rainfall variability is a permanent problem and it is no longer possible to expand their fields given the pressure on village land. Soil fertility is declining and so the family, unable to obtain more land, either has to incorporate fallow parts of the fields (which is not feasible) or intensify its soil management. The production and application of manure is a time-consuming and arduous task. To entice the young to remain on the farm during the dry season, the head of the family is 'investing' money in luxury goods such as bikes, radios and a motorcycle in an attempt to bribe them to stay.

The fate of the younger brother has been quite different. Having started in 1984 with many fewer assets than his older brother, things did not go so well. His family was plagued by illness and that demanded a lot of time and resources. Their journey to find the right treatment for their son brought them into contact with the Catholic mission who gave them food rations after ther conversion to Catholicism. Some familes in the village also befriended them and offered help.

The production deficit they have cannot be bridged by manual labour alone. However, they are far from being able to invest in a pair of oxen and agricultural equipment. The livestock they possessed - sheep and goats - have long since been sold to buy food. The only way out seems to be their children who will, in time, add to the family's labour force and this will allow them to expand production and undertake more remunerative off-farm activities. For the moment the playing of drums at ceremonies, festivals and Catholic rituals brings in most of their cash. The wife collects twigs in the bush to make 'toothbrushes' which she sells at the market in Koutiala. This activity brings in some money each week.

In another example, Nikiéma (1999: 68-71) shows how the splitting up of a family can turn out well for the people involved. However, this family too, has faced the problem of lack of land combined with variable rainfall and declining soil fertility. They are considering taking over land outside the boundaries of the village territory. The family has diversified with fruit trees (mangos) and market gardening, new varieties of maize, and labour migration to the town and to rural areas to guard livestock. The women in the family engage in all kinds of trade. Despite all these efforts, their cereal stocks have declined over the years. At the time of the research only one granary was left of the two that were held in reserve.

A major concern is the family's growing rate of indebtedness. Increasing demands for consumption have led farmers to take out large credits and the local banking system has not taken any measures to prevent indebtedness (Nikiéma 1999, Tefft 2001). This, in combination 
1998, 1999) have analysed their position "but do not give specific information about their pathways. Their numbers must be quite substantial because their presence is not limited to the villages around Koutiala (see Cissé 1993, Jonckers 1995, Koenig et al. 1998, 1999). The Dogon migrants are different from other groups of migrants in the sense that they often come from the same area of origin and cluster around several families in small hamlets, rather than living scattered over the territory of the host villages as other groups of migrants do. Often they are related by kinship and/or marriage. These relations are also the basis for their recruitment, with new arrivals first settling in a Minyanka village with people they are related to.

In many cases these families of migrants are only temporary inhabitants of the villages. Despite the fact that most families are recent arrivals, a number have already left again for places further south where there is less pressure on land or better economic opportunities such as in the towns of Koutiala and Sikasso. Some have even returned to their home areas in Koro (see 3.2 for an analysis of Dogon pathways in Koro) or Bankass Districts.

Migration is not a recent phenomenon among the Dogon. Since the beginning of the $20^{\text {th }}$ century they have colonised the Seeno and Gondo plains east of the Bandiagara Plateau (see Gallais 1975, Petit 1998), a process that still continues today. Dogon are also known as labour migrants in urban areas in Mali (see Mazur 1984). Mobility is therefore part and parcel of this population group's recent pathways though migration to the cotton-growing area around Koutiala.

There are few indications that the group of immigrants in the south of Mali is different in socio-economic and/or political respects to those that remain behind. They are reluctant to talk about their motives for settling in the south (Nijenhuis forthcoming). In general they arrive without any assets, i.e. with no livestock or farming equipment. In this sense they are not atypical in Dogon society in their home area because the head of the household often controls the stock of assets. Furthermore, people who depart are not allowed to take their share of the family's possessions with them.

The only way to escape this situation is by cultivating and building up a viable farming unit (Nijenhuis forthcoming). In their farming strategies they differ from Minyanka. They cultivate marginal land though no less than the Minyanka households (around 0.7 ha per capita) and are therefore less inclined to take out loans or assume risks for cotton cultivation. Nijenhuis (forthcoming) found that in one of her research villages only five out of nine families cultivate cotton and when they do they only cultivate a maximum area of 0.5 to $2.0 \mathrm{ha}$. However, the same could be true of other immigrant farmers (Bamana, Minyanka) living in this village.

Due to the low fertllity of their parcels of land and the lack of livestock to fertilise or add manure to the land, most ummigrant familes

\section{CLIMATHANGE IN MALI}

are not able to grow sufficient food and often have to buy additional cereals. This is in contrast to Minyanka farmers who have a mean surplus of almost $50 \%$. Given their weak tenure position, they are regularly chased off their land if the original owner sees fit to do so. There are also cases where they are victims of a conflict at a higher level.

\section{FulBe herdsmen}

There are two categories of FulBe herdsmen in the Koutiala area. The first consists of long-term immigrants who have either been herdsmen for the rulers of the Kenedougou Kingdom of Sikasso or are transhumants who have lived in the south of Mali for a long time. The main occupation of this group of FulBe is still cattle keeping. They are culturally FulBe though linguistically they have adopted Bamana as their mother tongue. No research has been done among this category of FulBe and no information can be found in the available literature. The second category consists of recent migrants. This migration wave started before independence, not only in the north of Mali but also in the northwest of Burkina Faso. Around one third of this category came before 1965 although immigration peaked after the droughts of the $1970 \mathrm{~s}$ and $1980 \mathrm{~s}$ (see also below).

The ways in which these migrants have assimilated into Minyanka society differ enormously. Some have been successful and have managed to build up a safe existence with more or less secure rights of access to resources. Van Steenbrugge (2001: 1-9) detailed the example of a family from the Bandiagara Plateau (see below) that managed to establish a complete well-equipped farming enterprise with fields planted with millet and sorghum, and a field devoted to growing cotton. The land was obtained from the local Imam. Their livestock is herded in the bush and they have been so successful that they earned sufficient money to enable the whole household to go on a pilgrimage to Mecca. Family members have travelled a lot and many relatives use this family as their point of entry into the region.

The more successful migrants develop an existence by trading livestock. Nevertheless, this can be difficult because of the capital required, the knowledge and the network of social relations needed and the potential risks. It is not uncommon for trading enterprises to collapse and go bankrupt (Van Steenbrugge 2001: 63-4). Others make use of the religious reputation of the FulBe and carve out an existence as a marabout, an Islamic cleric. They subsist on the payments and gifts they receive for providing religious services such as healing, the making of charms and amulets, education, and the agricultural labour and begging activities of their pupils. Such an existence implies considerable mobility: clients for religious services are widespread and the 
marabout's own religious knowledge has to be updated from time to time (Van Steenbrugge 2001: 66-67).

Other families are definitely in a less favourable position. They survive on temporary labour such as the herding of village cattle or they work for other FulBe in the region, or are involved in petty trade. Often these less successful families and individuals are much more mobile. They exploit opportunities in various places and make use of an extensive network of kin relations that gives them the chance to at least reside in some area on a temporary basis (Van Steenbrugge 2001: 5365). Young herdsmen are an example of this strategy: they are extremely mobile and hard to locate (De Bruijn 1998).

Only a few manage to subsist from the herding of livestock and most FulBe arrived in this region with no or few livestock. Pressure on land is quite high and there are only a few areas of refuge where cattle can graze in peace during the wet season. Moreover, villages in the area are trying to close their territories off to outside herds (like in 1999).

Another salient feature of this group of FulBe herding migrants is its association with other migrant groups from their own area, Dogon, rimaybe (former slaves) and artisans. These groups both participate in the local economy and perform services for the FulBe based on the division of labour in the home area (Van Steenbrugge 2001: 67-68).

\subsection{Douentza: La condition sahélienne}

Pathways to mitigate climate variability and other exogenous changes in the Douentza area are varied. They can be subdivided according to agro-ecological zone although they differ according to ethnic group and within these ethnic groups according to the position of the status group to which an individual belongs. A further subdivision can be made according to the degree of mobility of groups and individuals. Recent migrants from more northerly areas have developed distinct pathways. Given the differences between the various agro-ecological zones we will discuss pathways here according to zone.

The Bandiagara Plateau: Cereal cultivation, marginal livestock keeping and onion cultivation

The Bandiagara Plateau is an extremely harsh production environment. Officially one third of the area is bare rock. Another third consists of soils with a depth of less than $10 \mathrm{~cm}$. In addition, most soils are susceptible to seasonal drought given their shallow depth or physical properties (Cissé \& Gosseye 1991, GOM 1991). Consequently, around $15 \%$ of all the land is cultivable (GOM 1991). Population pressure is high with around 25 inhabitants per $\mathrm{km}^{2}$ or 190,000 inhabitants in the whole of Bandiagara District in 1991. Bandiagara District corresponds roughly to the area of the Bandragara Plateau, with the exception of the northern edge of the plateau that belongs to Douentza District. These

\section{CLIN CHANGE IN MALI}

people have to live off less than 48,000 ha of cultivable soll ( $6.3 \%$ of the total area) (GOM 1991: 12). In view of the soil fertility and potential production (between 300 and $800 \mathrm{~kg} / \mathrm{ha}$ ), cereal production is insufficient to feed the population. Between 1976 and 1987, 30,000 inhabitants left the area, which resulted in population growth decreasing from $3.5 \%$ based on natural fertility to $1.35 \%$. In some areas along the Bandiagara escarpment where population densities may reach 100 inhabitants per ha $\mathrm{a}^{-1}$, the population is even decreasing (GOM 1991).

In $1991,66 \%$ of the population was entrely dependent on dryland agriculture. Given the lack of land and the pressure of population, most land is cultivated on a permanent basis. The fertility of these soils is the most important constraint on cereal production as labour is available in abundance. Chemical fertiliser is hardly used for the production of cereals. Consequently, the repletion of soil nutrients is entirely dependent on organic manure in the form of animal dung, compost and household refuse. Most farming units have some small stock at the homestead to produce manure and make compost. Farmers also buy manure from FulBe herdsmen who have settled on the plateau, and herds of small ruminants and cattle are enclosed in fields needing fertilising. In 1991, it was estimated that more than 85,000 TLU were present on the plateau which exceeded its estimated carrying capacity by $100 \%$ (GOM 1991) However, it is highly questionable whether all this livestock is present al year round since most herds leave the area during the rainy season to pasture near the border of Burkina Faso, and leave the plateau during the dry season to make use of the pastures in the Inland Delta of the Niger. Only in the post-harvest season when harvest residues are present are large numbers of cattle to be found in the area. In the second half of the 1990 s, Dogon farmers started to remove residues from their fields to feed their own stock at their homesteads, making it even less attractive for livestock to remain on the plateau.

Pathways of Dogon farmers on the plateau emanate from a complex interaction between available assets in the form of land and plots for market gardening and livestock, markets for cereals, labour and vegetables (onions) and FulBe herdsmen. The most marginal Dogon, by far the majority, depend almost entirely on the cultivation of cereals and some monetary income from labour migration. These units have a yearly deficit and can only survive on cereals purchased in the market. Keita (1992: 8), in Van Beek \& Peters (1999: 109)) estimates that in the late $1970 \mathrm{~s}$ and $1980 \mathrm{~s}$, millet cultivation could not feed more than $40 \%$ of the population.

Farming units on the Bandiagara escarpment are better off because there is more land available at the base of the mountain and the soils in this area are better watered (Van Beek \& Banga 1992). This option has its limitations because population densities are very high on the 
escarpment and the productivity of the sandy soils of the Seeno plain under permanent cultivation (see below) is much lower than the land under permanent cultivation on the plateau.

Those who have access to plots for onion cultivation are able to generate some cash income to help close the cereal gap. However, the water resources for this type of strategy have only been developed in the central area of the plateau around Bandiagara and along the main transport axes from Bandiagara to Sangha, Dourou and Bankass. Between 1974 and 1987, 66 dams were built (Diawara 1987: 612) bringing the total area under irrigation to 863 ha (Keita 1992 in Van Beek \& Peters 1999) for 70,000 gardeners (Krings 1991: 223), which would mean that every gardener has access to no more than $125 \mathrm{~m}^{2}$. This is not a viable enterprise either for coping with the cereal deficit nor for increasing long-term income. Nevertheless, these tiny plots have become a replacement for staple food production. In some cases, extreme specialssation has occurred. Van Beek \& Peters (1999: 108), for example, mention that the women in a particular village specialised in the production of seedlings and have been quite successful since most male onion cultivators in the area now buy their seedlings from them. In the Sangha area there are families who rely more on onion cultivation as a subsistence strategy than on cereal cultivation.

Over the past years, this pathway has become less profitable because of the competition from other areas in Mali and the importation of European (Dutch) onions. Revenues from onion growing fluctuate and are declining in relation to cercal prices (Van Beek \& Peters 1999: 104 5). Moreover, there is a trade-off between market gardening and cereal cultivation because of the amounts of manure needed for gardens. In some areas livestock and cereal cultivation are not able to produce sufficient manure and compost for the gardens, let alone for the millet fields (Van Beek \& Peters 1999: 109).

Revenues from labour migration and market gardening are invested in the cereal deficit, in livestock to assist in soil fertility and as a source of capital. However, the possibilities for livestock keeping on the plateau are limited. For the herds residing there, the balance is precarious. The accessibility of feed for the animals is limited in the rainy season because of the cereal fields. During the dry season the quantity and quality of feed are low, the uncultivated soils produce very little biomass and the crop residues are harvested.

A limited number of FulBe livestock keepers (around 10\% of the population) are, nevertheless, trying to create an existence from livestock keeping by interacting with the Dogon. Often they live on the land of the Dogon, herd animals of wealthier Dogon farming units and camp on the margins of village territories. Although their pathways centre on livestock, they cannot manage without cereal cultivation as well. They either own too few cattle to be able to live off livestock products, or they do not own the livestock they herd and are therefore unable to market the animals (see De Bruijn \& Van Dijk 1999).

Fluctuations in rainfall and market price have a tremendous impact on the welfare and food situation of the inhabitants of this area. Though cereal fields may be quite productive on the plateau, the shallow soils make the crops susceptible to intra-seasonal drought. Drought years are marked by a massive outflow of labour from the plateau with people hoping to find employment in town. Most of this outflow is temporary though permanent migration is also an important phenomenon. The latter is a sensitive and painful issue as it is mostly the young who move away leaving the old who are opposed to their departure. Young families even leave Dogon villages in secret during the night. Among the FulBe, young herdsmen just depart under some pretext, leaving their parents, wives and young children behind ('he took up his herding staff and left') (De Bruijn 1998).

The Bandiagara Plateau is a risky production environment. Given the high population pressure, Dogon farmers respond by intensifying cereal and vegetable production. As an alternative, seasonal or long-term labour migration or even permanent migration are options for procuring income and food. Given the volatility of labour, commodity markets and prices, one kind of risk is exchanged for another. In between, FulBe herdsmen and their families occupy a separate niche on the margins of Dogon society created by the acquisition of livestock by the Dogon and the presence of a large area of marginal pastureland and the enormous demand for manure by the Dogon farming and vegetable-growing systems. A major question remains with respect to the farming and herding populations in the inaccessible rural areas where no hydraulic infrastructure has been constructed. These groups are exposed to evergreater risks because of the declining rainfall over the past decades and can only compensate for this by migrating on a temporary or permanent basis.

Plains. Livestock keeping, cereal farming, oasis, aid, trade

The constraints on pathways on the Bandiagara Plateau and escarpment have existed for a long time and have become an integral part of the most basic strategy of the Dogon for dealing with the chronic shortage of resources - agricultural expansion. The plains east of the plateau have been a major area for agricultural expansion over the past century (Gallais 1965, 1975, Brandts 2002, Petit 1998). 43 villages were established on the plains from 1905 to 1913,46 villages from 1914 to 1940 and 23 villages from 1940-1945 (Gallais 1975: 111). An east-west migration movement of Dogon to occupy the plains originated from the sub-district of Dinangourou (Gallais 1975) and a migration of Moss from Yatennga in Burkina who then settled to the east of Koro District 

o-thirds of all

ace, conditions the south of the orth of the drought risk 990: 9)

Specific cereal and livestock production systems have developed in with the help mers have only

The productivity of fields vartes according to area (north-south), type $\%$ (Hesse et al. l. 1985). The years 1982 and 1983 were drought years. In 1990-91, D Bru1jn \& Van Dujk (1995: 273) found production levels of around 350 $\mathrm{kg} / \mathrm{ha}$. For the southern plains, figures varied between 843 and 417 kg/ha (Harts-Broekhuis \& De Jong 1993. 194) during the 1980 s and around $340 \mathrm{~kg} / \mathrm{ha}$ in the 1970s (Eskelinen 1979: 258-59). On the plateau, productivity amounted to $630 \mathrm{~kg} / \mathrm{ha}$ (Eskelinen 1979: 258-59). Total cereal production in Koro District varied between 19,000 and 51,000 tons during the 1980s (Harts-Broekhuis \& De Jong 1993: 194)

With respect to livestock production, a similar story can be told. Livestock production varies with all kinds of ecological factors. Biomass production fluctuates with a standard deviation of around $40 \%$ (De Bruijn \& Van Dijk 1995; 284). Time and again disasters, such as the death of large numbers of animals, occur due to dehydration and starvation. This happened in the 1970s and again in the 1980s. The total number of cattle decreased by probably as much as $60 \%$ from 1970 to 1985. After 1985, numbers began to increase again although exact cattle figures are difficult to assess since the number present varies according to the season and to specific pasture conditions in the area within the seasons. It is often not clear where the home basis of the owners of many of the animals is and how much time they spend in the study area compared with other areas.

\section{Case studies}

The whole study area is one of variations in a climatic and an economic sense, both on the plateau and on the plains. This renders the population extremely vulnerable. Some examples of the diverse ways in which various population groups respond to these changes are considered below, although the data only partly reflects reality. There is much more variety than can be shown in a small number of short case studies. Nor is it possible to give an account of the people who did not manage to survive in the study area and have since left, or those who gave up or died under the impact of ecological stress. A number of families have been followed closely for 13 years by the authors and on a recent visit, in January 2002 , this process became apparent. See also the case studies of the FulBe below.

\section{Dogon farmers}

On the Bandiagara Plateau, cereal cultivation has become so marginal that there is an increasing number of production units subsisting almost entirely on non-subsistence agriculture supplemented with income from labour migration (see Van Beek \& Peters 1999). Investments are made in the expansion of their cattle herds, while outside agencies occupy themselves with the physical infrastructure for cash cropping. This general evolution towards commercialisation may well be a dead-end street. Given the tiny plots available for onion cultivation (average $125 \mathrm{~m}^{2}$ ), the limited scope and the increasing unit costs for the expansion 
of irrigated areas and the compettion in the onion market, the likelihood of sustained income growth is low.

Prospects for the expansion of production are somewhat better on the plains. However, growth can only be sustained if land is still available for agricultural expansion. If this is the case, this strategy could be successful. Cereal production on the plains is quite high given the quantities (around 3,000 tons per annum) being sold to people from the north who are coming into the area specifically to purchase cereals (Rutgers Van Der Loeff 2001) The cereals transported to the markets in Bandiagara, Mopti, Douentza and Booni on the backs of donkeys, using donkey carts and by truck are not included in this figure. These quantities are also considerable.

As the examples show, even in marginal conditions in the north of the study area, a concentration on cereal cultivation can be quite successful if it is supplemented with other sources of income and/or labour. The Dogon believe that if they have a large family they will be more successful as the number of children under the control of the head of the household determines how much land can be cultivated. The only way to do this is to expand production and work very hard. Maas (2001) discusses a household with 49 members of which 15 are pupils of a family member who is an Islamic teacher. This household is located in a village on the plain that grew out of a temporary cultivation hamlet. This hamlet became a permanent village when the government livestock service established a well for the pastoral FulBe in the area. Incidentally, it promoted the settlement of Dogon cultivators.

This household compensates for bad years using the income of the Islamic teacher. In 1997, after a bad harvest, he supplied the family with 250,000 CFA francs and 2 tons of cereals. The other (young) men in the household went into the cereal trade and family members gathered Boscia senegalensis berries as supplementary food. In the end, no food had to be bought and capital reserves in cattle and agricultural equipment were not depleted. In a normal year, the food needs of this household are largely covered and cereals can be stored for bad years. In 1998, this household harvested $8,375 \mathrm{~kg}$ or $168 \mathrm{~kg}$ per capita $(243 \mathrm{~kg}$ per capita without the Koranic pupils who would have been away during the dry season) (Maas 2001: 14).

Small farming units can also be successful, especially when adult labour is abundantly available. One family of five recently set up a separate family unit when its head came back from a prolonged period of labour migration to Bamako, the capital of Mali, and no longer wanted to work for the less productive members of his family. During the slack season, he and his brother work for a butcher in Mopti, the regional capital about 200 kilometres from the village. They produced $3,600 \mathrm{~kg}$ of millet in 1998 or $720 \mathrm{~kg}$ per capita (Maas 2001: 18).

Both famlies own a number of livestock (more than $20 \mathrm{TLU}$; TLU $=$ Tropical Livestock Unit, 1 head of cattle is $0.7 \mathrm{TLU}, 1$ camel $=1 \mathrm{TLU}, 1$

\section{CLIMAT YANGE IN MALI}

goat or 1 sheep $=0.1 \mathrm{TLU}$ ). Livestock is used as a cash reserve and to apply organic fertiliser to the soils. Both families enclose their livestock on their fields and try to persuade FulBe herdsmen to settle temporarily on the fields with their animals.

Farming units are in a different position. Brandts (2002) discusses the case of a middle-aged farmer in a village close to the Bandiagara escarpment who is the descendant of a migrant. He has only small fields, which he borrows from a family of autochthones. The fields are far away from the village and he does not have the means to invest in agricultural equipment. During the dry season all his sons work in town to make ends meet and he himself works as an agricultural labourer during the growing season.

\section{FulBe herdsmen}

The droughts of the 1970s and 1980s have had a tremendous impact on the pathways of FulBe herding groups in the area (data on the FulBe were gathered from 1987-2002 over several fieldwork periods (1987, $1990-1992,1997)$ and short visits $(1995,1998-2002)$ by the authors). Before the droughts theirs was a relatively easy form of subsistence based on a herd of cattle which yielded sufficient milk to cover either a significant part of the food needs of the family or, when bartered, brought in enough cereals to feed the family for part of the year. With the droughts, they were not only confronted with famine and a massive loss of livestock, but also had to face increasing competition for land from the Dogon who expanded cultivation and have to compete for pastures with incoming herds from the Inland Delta of the Niger. A lot of FulBe failed to cope with this situation and migrated to areas like Koutiala District (see above) or to major towns. Numerous families collapsed and became dependent on urban and sedentary livestock owners for employment and some (mostly very little) social protection. These families ended up on the margins of society. Young men, in the absence of livestock to herd and without prospects of employment, left in large numbers with sometimes devastating effects for the women, children and the old who remained behind (De Bruijn \& Van Dijk forthcoming, De Bruijn 1998).

Those who stayed in the study area slowly started to rebuild their lives after the droughts. Their living conditions have improved slightly although their experiences have been mixed. For example, one family had the chance to herd a trader's cattle which enabled them to drink the herd's milk while economising on cereals and to build up a herd of goats to act as a buffer in times of food shortage in subsequent years. If necessary, the goats could also be converted to cash. Given their political position, they also had preferential access to a dry-season grazing area. These factors promoted the reconstitution of the cattle herd. Investments were made in a plough with camel traction to expand cereal cultivation 
and to facilitate transport. Some years later, a donkey cart was bought to transport water to temporary cattle camps in the bush, to enlarge the herding orbit and to open up access to faraway pastures for the cattle and goat-herd. Quite unusually, none of the sons left the family to try their luck in town or elsewhere. In 2002, 17 years after the drought, the family was prospering and had doubled in size.

The fate of therr neighbours was quite different. This family, consisting of three brothers, their wives and children, also lost most of their livestock during the drought. One brother left after a quarrel, the second decided to move south to settle on the land of a Dogon farme and to concentrate his efforts on small ruminants, and the eldest brother decided to bet on reinvesting in cattle in combination with cerea cultivation and to remain in his cattle camp. None of them was successful. The family of the brother who left suffered tremendously and only survived on a combination of herding labour for Dogon farmers away from home, seasonal labour migration, charity, the gathering of bush products (very humiliatung for a noble pastoralist family) and cereal cultivation. In the end, the girls were decently married off, the father and the sons returned and they resettled in their home camp. The second brother remained in the village of his Dogon patron for 10 years, surviving on the most meagre means imaginable. Upon his return, he and his wife were so exhausted by the suffering they had experienced that they both died within a couple of years of each other.

The eldest brother also had a hard time. He decided to stick to cattle and to work hard at cereal cultivation with his sons to rebuild the herd. This proved an extremely difficult strategy. The gain in herd size durng good years was cancelled out in bad years when he had to sell cattle to buy food. His sons ran away all the time to work as cattle herdsmen elsewhere and their contribution to the family was limted because their wages were low and they preferred to spend their earning on radios and cassette players. However, he was lucky in that one of his daughters, contrary to cultural conventions, married a well-to-do Dogon trader who helped the family during hard times. A second daughter, though unable to bear children, became the favourite wife of an important Muslim scholar in the area and was able to give some things to her parents as well. During the post-drought period, no investments were made to expand the famuly's productive base. Some gains were made in the number of livestock owned but the family fields were not fertilised and cereal yields started to decrease.

Riimaybe

Traditionally, the rimabe, the former slaves of the FulBe, were at the bottom of the social hierarchy in the area. In the past, they were the first to suffer in situations of scarcity and the last to benefit from a period of prospenty. In a number of respects, they are still more vulnerable than other groups in FulBe society. At the same time, given therr status and their attitude towards wage labour, they are able to respond much more flexibly to new opportunities than their FulBe overlords (De Bruijn \& Van Dijk 1994). However, a distinction must be made between those who still belong to the network of clients of the noble FulBe and live near their former masters and those who have always lived in separate villages. Whereas the former still have to make contributions in kind and labour to the welfare and the household of their masters, the latter have managed to gain a certain measure of manoeuvring space both in an economic and a political sense.

Revenues from cereal cultivation are generally insufficient to cover the food needs of a family. All kinds of activities and seasonal labour migration are undertaken to close the cereal gap and to cover other expenses. For example, a family of nine people might cultivate three millet fields that yield between 30 (1997) and 80 (1996) bundles of millet (about 600 and $1,600 \mathrm{~kg}$ of millet respectively when the bundles are large). One of the sons settled permanently in town and does not contribute to the family. The second son is married and works temporarily in town each year as a weaver. This does not bring in a lot of money but at least he no longer makes demands on the household budget. His wife has a personal field, which yielded another 6 bundles of millet in 1998. She cultivates about $50 \mathrm{~kg}$ of rice in the pond next to the village and waters an onion garden every day. She and her mother-in-law also weave mats of palm leaves after the harvest, bringing in 125-150 CFA francs a day if she works very hard. In addition, she took out a loan with a women's credit association, which allowed her to buy goats. She is paying back the money with the revenues from her mats and by speculating on the livestock market with her goats. The revenues from this large spectre of activities are small and do not offer much scope for expansion. Misfortune in the form of a sick family member or a bad harvest may seriously jeopardise the family enterprise.

Among the rimaybe the diversification of activities is enormous. Griep (2001: 92-93) mentions a woman who raises small stock at her homestead, cultivates rice and millet on her personal fields, engages in petty trade and participates in activities organised by development organisations, all in addition to her household chores. In other places where cereal production is better, the women will engage in fewer activities.

An important aspect of the development of new pathways is investing in dry-season water resources. Ponds and wells are being managed in new ways so that better use can be made of the water, and even food crops, such as beans and cash crops like garlic, perennial cotton, pumpkin, mangos etc, are produced in oases-like units. While developing these water resources, the riimaybe make creative use of the 


\section{ANALYSIS AND CONCLUSION}

In the concluding section of this chapter, two sets of questions are discussed. The first relates to the commonalties and differences between the two study areas. How can the structural differences between the areas be appreciated and how can these relate to the exposure to risk and the pathways people develop to mitigate these risks? The second set of questions is related to discussions concerning policy development and focuses on the specific role of climate variability within the study areas and the possible consequences of climate change. As a starting point one of the scenario baselines is used, as outlined by Van Den Born et al. (2000; also see chapter 5), predicting a decrease in rainfall in Koutiala of approximately $25 \%$ and in Douentza of approximately $50 \%$ and a substantial increase in variability and risk.

It is obvious from the discussion of the two study areas that the differences are vast and pervade all aspects of life. The differences are not only confined to climate and climate variability and the physical properties of the areas but can also be found in the institutional and economic context and the socio-cultural set-up of the areas, though the latter have developed due to interaction with climate and the environment.

A point common to both areas is the high level of risk in agricultural and economic activities in general. These risks are the result of the variability of the climate and of the economic context in the form of cereal and cotton markets. Moreover, in the local and even in the personal context, further risks can be identified pertaining to health micro-climatic conditions and pests. Solutions are found in the diversification of activities in combination with mobility in the form of labour migration or permanent migration, and even in the set-up of multi-spatial livelihoods (cf. Foeken \& Owuor 2001). In a number of cases, therefore, a much wider range of factors should be taken into consideration than the conditions in the study area alone. Individuals also make decisions with respect to investments in agriculture and their home area not only with a view on the conditions in place but also while bearing in mind the possibilities elsewhere. This will only become clear when considering the individual case studies as collected over the years in more detail than is possible in this chapter. The role of individual differences as an explanatory factor for the diversity of specific pathways of households and individuals and any other decision-making units cannot be stressed enough in this respect. Hence there is a need for a methodology that goes beyond this enormous variety in responses and

focuses much more on the processes of decision-making under high-risk conditions (See Chapter 18).

Comparing the two study areas yields the same focal points as the most relevant for the understanding of pathways to mitigate climate variability and climate change. In both areas a number of factors seem to structure pathways: access to resources, ethnic and social identity, and life-history events. There seems to be no single development path related to resource endowments, ethnic identity and/or life-cycle events. It can be argued that specific pathways cluster in certain groups of people, such as the preference for livestock keeping and a high degree of mobility among FulBe pastoralists, as well as the preference for cereal cultivation and a more sedentary mode of existence among Dogon, riimaybe and Minyanka farming groups. However, this does not rule out the fact that large numbers of farmers are also mobile both within the study areas and beyond. In general, people in Douentza seem more mobile than those in Koutiala, given the higher degree of risk embedded in the ecological environment and the technology available to mitigate these risks.

However, the role of contextual factors differs substantially between the areas. Rainfall variability and, in its wake, soil quality (expressed in water-holding capacity because differences in soil fertility are not that important) play a much larger role in Douentza than in Koutiala because of the more irregular rainfall patterns. These differences are directly reflected in food security. In Douentza most farming and herding units have a food deficit in most years, whereas in Koutiala most farming and herding units are food secure in almost all years. Cereal productivity is much higher in Koutiala, especially that of maize that cannot even be cultivated in Douentza, and there are fewer fluctuations.

In contrast, governmental and non-governmental interventions seem to play a more important role in Koutiala than in Douentza in shaping individual pathways. In the Douentza area, outside interventions are not able to produce more than a marginal increase in income, whereas they have a direct impact down to the village level and on a number of aspects of the functioning of the farming unit in Koutiala. Because of the particular form of interventions in Koutiala, they seem to enhance the risk through the increasing indebtedness of farmers and their reliance on volatile markets for export commodities. The low labour productivity of cotton cultivation and constant pressure from the Cotton Company to produce more puts a premium on the depletion of soil fertility. One cannot blame farmers for being price responsive and for not investing in soil fertility if this lowers their marginal returns on labour below their opportunity costs.

An important feature of individual pathways is the mobility across regional, agro-ecological and social boundaries. This is most significant in the case of the Douentza area. This mobility occurs at all levels - 
local, regional, sub-regional, national and international. There is no household without experience of mobility and there is no continuity without income from outside, except for some individual cases where consumption demands are still limited.

Though specific pathways cluster in certain areas with particular groups, the range of options is enormous. Within the FulBe, a distinction can be made between the nobles and the riimaybe, between the people living in their home area and those on the fringes of sedentary villages. Within the sedentary groups a distinction must be made between what can be labelled the autochthones and the immigrants, the latter in general being in a less favourable position with respect to access to resources. This does not mean, however, that those within the same cluster follow similar pathways. The examples of the three FulBe brothers in Douentza and the two Minyanka brothers in Koutiala show how different life can be even for people with the same starting position. Pathways also cluster on a regional basis and within specific regions. They develop in response to distinctive contextual factors, in this case rainfall, landscape and associated soils, and the rainfall gradient (see also Brons et al. chapter 16).

This grouping of pathways and the patterns that emerge from a detailed overview make it possible to look to the future and project existing trends of mitigation of climate varıability in the future. We have chosen for a scenario of a $50 \%$ (Douentza) and $25 \%$ (Kout1ala) decrease in precipitation. This is a worst-case scenario. However, the reverse increase in precipitation would create as many but different difficulties for these changes would upset the water balance of the whole region and lead to increased flooding and the need to adapt cropping patterns, which would require as much adaptation as would a decrease in rainfall.

Douentza

The consequences of the drought scenario are huge and would result in a major shift in pathways. With rainfall of around $200 \mathrm{~mm}$ in the Douentza study area, current and already low levels of cereal production could not be maintained and would be reduced to almost zero. Only in depressions and near water holes would there be any possibility for oasis-type farming systems and dry-season cultivation systems, as presently found on the Bandiagara Plateau and in some places on the plains. Those with no access to these water sources would have to shif from cereal cultivation in Douentza to extensive livestock keeping, in combination with the gathering of wild grains such as fonio (Panicum laetum) and cram-cram (Cenchrus biflorus).

The development of these oasis-type agricultural systems in the Douentza area would require large investments in hydraulic infrastructure and the development of marketing channels for the cashcrop-oriented production. Given the fallure of local cereal production systems, these investments could only be made with the help of outside agencies or on the basis of the remittances of migrants from the area Neither source of investment would be assured and, given the current levels of investment, it is highly unlikely that sufficient production capacity could be created in this way.

In addition it is to be expected that more ecological refugees from the north would arrive in the study area and clog up the towns (at least this was the case in the 1970s and 1980s) or they may start wandering through the area looking for food and water. This would put extra pressure upon production systems that are already under stress.

Given the current lack of non-agricultural sources of income in Douentza it is improbable that labour-intensive non-agricultural activities would develop here. The other options, i.e. gathering activities and extensive nomadic livestock keeping, would not be able to absorb the surplus labour from cereal cultivators who had been forced to abandon their activities. Because of the decreasing amount of rainfall and the increase in variability, the uncertainty about the productivity of the natural environment would augment and its absolute value decline. The capacity to produce sufficient food in the form of wild grains and livestock products would diminish. Food would either have to be imported from outside or people would have to move out of the area.

Kouttala

A different scenario can be drawn for the Koutiala area with no fewer consequences and with a severe impact on the national economy of Mals A decline of $25 \%$ of mean annual precipitation would make the cultivation of cotton and maize impossible in large parts of the study area. Only in the south, where rainfall levels of around $800 \mathrm{~mm}$ are present, would cotton and maize continue to be important crops. This would deal a major blow to the economy in the area and in Mali as a whole, since cotton presently accounts for $50 \%$ of export earnings and it would also virtually wipe out most of the employment in the industrialised cotton sector. Urban areas would no longer be the motor for economic development in the area and would not be able to absorb surplus labour.

The most viable alternative for the farming and herding population would be to develop the intensive cultivation of cereals See, for example, Toulmin (1993) for a description of similar processes in more northern areas of Mali during the 1970s and 1980s). The main bottlenecks for this intensification process would be the variable amount of rainfall and the maintenance of soil fertility. It would not be profitable to use chemical fertilisers for food crop production and, given the high population density and the amount of land already under cultivation, there would not be sufficient space to produce organic manure from livestock. 
Moreover, the Koutiala area would almost certainly become a major area of refuge for people from the north who would have to move when their home area becomes too dry. Already there are problems with absorbing the numbers of FulBe and Dogon migrants in Koutiala. In other parts of the south of Mali, there is still some space but there too production would decline as a result of deteriorating rainfall.

An enormous increase in population mobility would act as the main pathway for coping with change. Farmers and herdsmen who lose a substantial part of their cash income would try to compensate for this with seasonal labour migration to nearby coastal countries. Permanent migration of families and individuals would increase dramatically. Those who remain behind would become increasingly dependent on external sources of income and aid.

We will not venture here into the possibilities of increasing conflict due to more intense competition for resources because the relations between scarcity and conflict have not yet been established with any certainty. However, the chances of civil unrest are considerable given the near total disruption of rural and urban production systems, the adaptations that would have to be made at all levels of society and the emergence of large numbers of people wandering around the countryside looking for food. It is almost certain that such changes would have some impact on relations with neighbouring countries too, because there would be an enormous outflow of people from both the study areas and the whole zone would suffer from climate change. Providing the affected zone with new sources of livelihood and providing all migrants with a new basis of existence would be the main problems for policy makers in this part of Africa if the climate were to change to the extent that such major disruptions in these vulnerable economies occurred.

Chapter 14

\section{RESPONSES TO CLIMATE VARIABILITY IN THE KAYA REGION, BURKINA FASO}

Mark Breusers

Abstract: This chapter provides a detailed historical account of changes in the Kaya Region of northern Burkina Faso, an area that was selected as an example of the most difficult conditions in the West-African drylands' semi-arid, rural, high population density and relatively high levels of land degradation. Climate change and climate varability are put in a perspective along with many other factors such as the impact of colonialsm popuation growth and long-distance migration mainly to the Cote d'lvoire, the world market for coffee, and cocoa and recent political developments in Burld market for coffe, and cocoa, and recent political developments in Burkits resulled in a shif towards diversifed livelihoods and multi-locational security networks and to changes in kinship relationships. Flexibility has understood by development planners involved in the area.

\section{INTRODUCTION}

The Kaya region is located in the Sudano-Sahel zone of Burkina Faso and covers the Bam province, most of the Sanmatenga province and smaller parts of the Yatenga and Soum provinces. The region is essentially rural, with only Kaya, the sixth town of Burkina Faso, being urban in character. Although diverse agro-ecological niches are encountered throughout the region, the overall variability in agro ecological conditions is relatively limited. The tree savannah vegetation changes from north to south, with thorn bushes, which are gradually receding for dispersed trees and with a more dense tree vegetation occurring along the valleys of seasonal rivers and rivulets. Soils vary mainly in accordance to slopes and erosion and deposition by seasonal rivers. Sandy and gravely soils, with a low water retention capacity, dominate higher up the hills. They are often heavily degraded, have a 207

As Dietzet al (eds). 